\title{
Deslegitimando los estereotipos pictóricos españoles: de Equipo Crónica a Antonio Saura
}

\section{Delegitimizing Spanish Pictorial Stereotypes: From Equipo Crónica to Antonio Saura}

Iñigo Sarriugarte

Universidad del País Vasco, España

inigo@inigo77.jazztel.es

\section{Resumen:}

A partir de las restrictivas normas culturales y artísticas, que se imponen en la España franquista, una serie de creadores se lanzan en un proceso de deslegitimización pictórica en torno a toda una serie de estereotipos culturales españoles. Entre estos creadores, encontramos el grupo Equipo Crónica, que se embarca bajo los condicionantes del realismo social en una batalla por satirizar y ridiculizar aquellos baluartes de la cultura artística española durante los años 60, que eran radicalmente defendidos por el régimen franquista. Realizan parodias culturales, que arremeten contra artistas convertidos en mitos, como El Greco, Velázquez, Rivera, Zurbarán y Goya, entre otros. Por otro lado, bajo un lenguaje cercano a la neofiguración que se da a partir de finales de los años 50, Antonio Saura arremete en sus Retratos imaginarios con violencia creativa contra estos mismos estereotipos.

Palabras clave: estereotipo, franquismo, España, Equipo Crónica, Antonio Saura.

\section{Abstract:}

From restrictive cultural and artistic regulations, imposed by Spanish Francoism, a groups of artists begun a process of pictorial illegitimatizations towards a series of cultural Spanish stereotypes. Among these artists, there is the group Equipo Cronica, who used features of Social Realism in a battle for satirizing and ridiculing Spanish culture during the 60s, radically defended by Franco's regime. Crónica performed cultural parodies against myths like El Greco, Velázquez, Rivera, Zurbarán and Goya. On the other hand, with a language close to Neo figurative art that appeared by the ends of the 50 s, Antonio Saura created his Imaginary Portraits with an imaginative violence against these same stereotypes.

Keywords: Stereotype, Francoism, Spain, Equipo Cronica, Antonio Saura. 
Los estereotipos son verdades cansadas

George Steiner

\section{Introducción a la cuestión de los estereotipos artísticos}

Los estereotipos se pueden definir como creencias sobre colectivos humanos que se crean y comparten en los grupos de una cultura, los cuales se llegan a trasladar a modelos culturales y a la percepción de patrones artísticos de otras culturas. En general, el estereotipo se puede asumir como una forma inferior del pensamiento, ya que no coincide de manera exacta y exhaustiva con la realidad, siendo este motivado en numerosas ocasiones por condicionamientos etnocéntricos o bien como una creencia exagerada asociada a una categoría (Allport 187).

El tema de los estereotipos étnicos ha sido tratado por diferentes autores como Brigham, Vinacke, Mackie, Secord y Backman, entre otros, llegando a la conclusión de que se trata de una generalización relacionada a una determinada característica de un grupo étnico, que puede ser injustificada por parte de un observador objetivo, definida en un consenso de opinión respecto a los rasgos de dicho grupo ${ }^{1}$. En este sentido, el estereotipo cultural o artístico se presenta como una característica negativa sobre la base de conceptos aprendidos erróneamente o exportados por intereses subjetivos.

Cuando hay un consenso social respecto a un estereotipo concreto se le añade el calificativo cultural. Este hecho se puede extrapolar a las artes plásticas, cuando constantemente se relacionan las pautas artísticas de un país o una cultura con imágenes determinadas, figuras y escuelas, y se les considera representativas de toda una cultura nacional, mi- nusvalorando otras pautas artísticas tan representativas, o aún más, que las alzadas como principales. En este caso, el objetivo sería "reemplazar socialmente el estereotipo negativo a través de un grupo de compromisos más constructivos" (Fishman 58).

Asumir una cultura pictórica bajo una serie de estereotipos resulta un factor subjetivo a la hora de enclavar una cultura y mostrarla en contextos internacionales. De ahí que ciertos grupos artísticos y creadores hayan intentado luchar contra este factor, especialmente en España, donde la realidad artística queda continuamente mediatizada por los grandes maestros de la pintura del Siglo de Oro. El ambiente artístico español siempre se ha presentado estático, lo cual lleva a ciertos creadores a actuar en respuesta de eso con el objetivo inmediato de arremeter no solo contra ciertos estereotipos artísticos, sino incluso contra el régimen político que los difunde. La reacción tanto del gobierno franquista como de numerosos espectadores fue claramente crítica y recelosa. No obstante,

1 Resultan de gran interés los siguientes artículos: Brigham, J. Ethnic stereotypes. Psychological Bulletin 76 (1971): 29-31; Vinacke, W.E. Stereotypes as social concepts. Journal of Social Psychology 46 (1957): 229231; Mackie, M. Arriving at truth by definition: The case of stereotype inaccuracy. Social Problems 20 (1973): 435; Secord, P.F. \& Backman, C.W. Social psychology. New York: McGraw-Hill, 1974. 
los sectores más progresistas comenzaron a entender los trabajos de estos creadores como una lucha social, cultural y política contra el régimen de Franco. En este sentido, se ha intentado con los trabajos de ciertos colectivos e individuos eliminar el absolutismo de las creencias pictóricas existentes en el resto de países en torno a España, ya que esta ha sido una forma constante de caracterizar a un exogrupo (Katz 181) quedando otras formas y maneras comunicativas totalmente marginadas.

\section{Introducción a la situación artística en la España de los años sesenta}

La Guerra Civil supuso un duro retraso para el proceso artístico que se estaba produciendo en España: en muchos casos las actividades culturales pasaban a segundo plano debido a la urgente necesidad de defensa política o humanitaria que se empezaba a requerir. Para Bernat Muniesa:

Tras el paréntesis de la Guerra Civil, la cultura en sus diversas facetas se colapsó. Es como si el enorme expansionismo de los años veinte y treinta, con sus clasicismos y vanguardismos, hubiera alcanzado los límites de su universo y, por una fuerza de contracción, se replegara hacia un núcleo. Esa fuerza fue el Nuevo Estado Español: en el repliegue retrógrado fueron expulsados los clasicismos molestos y las insolentes innovaciones (77).

La situación bélica supuso un retraso para los vanguardistas españoles. Para muchos, esta situación suponía el exilio y el abandono de su país y con ello el foco de influencia cultural que podían ejercer en el resto de artistas ${ }^{2}$, para otros, el asentamiento en un nuevo sistema que no veía con muy buenos ojos las diferentes investigaciones que se realizaban en la vanguardia. Otros artistas, en cambio, deberían todavía continuar en el extranjero, ya que estaban instalados fuera de España antes de la guerra, caso de los miembros de la Escuela de París.

En el periodo de posguerra y en el autárquico, el arte se volvió académico, la pintura se acercó a las fórmulas del paisajismo y la plástica retomó la copia de modelos con la consiguiente revalorización del clasicismo. En este sentido, los años 40 fueron un desierto para las posturas de vanguardia, por la clara posición contraria de las instituciones culturales

2 Existen numerosas publicaciones que abordan la situación del exilio en artistas, escritores y diferentes personajes relacionados con la cultura. Por ejemplo, destacan las siguientes publicaciones: AA.VV. 60 ans d'exil républicain: des écrivains espagnols entre mémoire et oubli, número monográfico de la Revista Exils et Migrations Ibériques, coordinado por Manuel Aznar Soler, Nigel Dennis y Bernard Sicot, París, Université de Paris 7-Denis Diderot/CERMI, 1999; AA.VV. Castellanos sin Mancha. Exiliados castellano-manchegos tras la guerra civil. Madrid: Celeste Ediciones, 1999; AA.VV. El exilio teatral republicano de 1939. Sant Cugat del Vallès: Associació d'Idees/GEXEL, 1999; AA.VV. Enfants de la guerre civile espagnole. Vécus et représentations de la génération née entre 1925 et 1940. París: L'Harmattan, 1999; AA.VV. L'émigration: le retour, Clermont-Ferrand: Université Blaise Pascal, 1999; Dreyfus-Armand, Geneviève. Exil des republicains espagnols en France: de la Guerre civile à la mort de Franco. París: Albin Michel, 1999; Santos, Félix. Exiliados y emigrados. 1939-1999. Madrid: Fundación Españoles en el Mundo-Cuadernos de la Fundación, 1999. 
franquistas y por la gran ausencia de numerosos intelectuales y artistas. En estos mismos años aparecieron movimientos destacados -Dau al Set, Escuela de Altamira, Grupo Espacio- pero no tuvieron un claro asentamiento en la sociedad. Son años donde se impone un costumbrismo académico y convencional, resultando este estilo el que marca el gusto oficial. El carácter totalitario del régimen franquista planteó un fuerte intervencionismo en los campos de la cultura y el arte, ya que estos medios podían servir como elementos de imagen y propaganda del régimen. También se dedicó a censurar todos aquellos elementos culturales que no conectaban con el gobierno franquista. Como bien afirma Manuel L. Abellán: "la censura, robustecida y potenciada por toda la gama de actividades y funciones que fueron vertebrándose en ella, fue concebida como tarea encaminada a establecer la primacía de la verdad y difundir la doctrina del Movimiento" (15).

Numerosos críticos y artistas que defienden el nuevo orden se lanzan en la redacción de postulados en favor de un arte del régimen, apoyando el papel intervencionista del Estado en el arte; la condición jerárquica de las artes; la concepción corporativista del artista asociado gremialmente al Estado; la afirmación y desarrollo de los valores tradicionales en el arte y el fomento de exposiciones nacionales. Estas últimas "parecían empeñadas en no reflejar ni el nivel de producción artística ni el censo completo de los artistas con interés, y mucho menos, en favorecer cauces para la transformación del panorama artístico" (Ureña 27).

Los años cincuenta suponen parcialmente un desbloqueo internacional de España respecto a las democracias occidentales, lo cual favoreció la permeabilidad cultural y artística en conexión con otros países. La información fue en general de mayor calidad, siendo aprovechada por los artistas. De esta forma se pretendió impulsar una homologación con la Europa occidental. Muchos de los artistas podían salir al extranjero, lo que posibilitó la recogida de información de primera mano para traerla posteriormente a España. En zonas más industrializadas, como Barcelona, este anhelo de internacionalismo fue mucho más marcado debido a la oposición que mantenía la clase intelectual catalana con las instituciones franquistas.

Desde amplios sectores artísticos, se observa un apoyo y seguimiento al arte abstracto y las corrientes informales frente al academicismo; se ataca todo elemento propagandístico que afecte a la libertad, es decir, se pretende una renovación radical que cambie la situación actual del arte español, buscando nuevas orientaciones que fortalezcan ese posicionamiento aperturista. Es evidente que en esta década se produce una clara convergencia entre la vanguardia artística y la vanguardia política, separándose ambas de los postulados oficiales (Serraller 116). Esta conexión tuvo efectos positivos y desencadenantes para muchos artistas con un claro impulso en favor de los lenguajes experimentales. Como bien afirma Álvaro Soto Carmona:

a finales de los años cincuenta confluyen una oposición exterior cada vez más testimonial y alejada del país y una oposición interior, que ya ha participado en algún tipo de protesta, y que es consciente de los cambios, que se están produciendo en la sociedad española, lo que le conduce a fórmulas menos dogmáticas y más pragmáticas en sus planteamientos. Este cambio coincide con un relevo generacional (111). 
El poder oficial fue abandonando sus pretensiones de extender un arte imperial y con el desarrollo de la década de los cincuenta comenzó a apoyar tímidamente a las vanguardias locales, aunque su apoyo fue más simbólico que efectivo. Por otra parte, a principios de los años sesenta, se puede encontrar ya una cierta madurez en la obra de muchos creadores; parece que los artistas se adelantan y se van homogeneizando a ciertas pautas del resto de países europeos. Desde diferentes ámbitos, se continúa produciendo un acercamiento a los países occidentales; no obstante, el gobierno franquista mantenía estructuras rígidas a nivel político y económico que impedían este acercamiento. Como bien afirma Valeriano Bozal, "ni el país ni los artistas estaban para tradiciones y academias" (94).

Los años sesenta, desde sus comienzos, están marcados por una fuerte actividad de huelgas y creación de grupos estudiantiles antifranquistas que responden con violencia ante la policía en Madrid, a raíz de la expulsión a perpetuidad de los catedráticos Enrique Tierno Galván, José Luis López-Aranguren y Agustín García Calvo de sus respectivos puestos en la universidad (Malerbe 16). Estas huelgas vinieron acompañadas de una serie de cartas elaboradas por intelectuales españoles ${ }^{3}$, donde se pedía una lealtad informativa por parte del gobierno, la prensa y las radios nacionales. Además, se abogaba por la normalización del sistema de negociación de las reivindicaciones económicas por los medios con renuncia a los métodos represivos. Entre los intelectuales que elaboraron estas cartas se encontraban Ramón Menéndez Pidal, Vicente Aleixandre, Torrente Ballester, Buero Vallejo y Goytisolo, entre otros.

Debido al enrarecimiento del ambiente socio-político, los artistas plantearon un enfrentamiento contra los valores del sistema, entre ellos, los estereotipos pictóricos y culturales que se exportaban continuamente por parte del franquismo como modelos representativos de la totalidad cultural española. Durante esta década, se desarrollan los medios de masas, es decir, España se polariza hacia los modelos de las sociedades industriales occidentales. De hecho, se atisbaba un boom económico por la apertura de las fronteras del país y una tímida liberación del régimen, que evidenciaba su descomposición paulatina. Estos hechos crearán un ambiente propicio para la creación de un arte experimental. Por otra parte, en España, se instalan diferentes corrientes internacionales artísticas que mantienen una relativa puntualidad con las que se producen en Europa. En este sentido, se comienza a disponer de todo un conjunto de movimientos artísticos que, según se iban produciendo en el extranjero, se instalaban en este país en pocos años, como el pop art y el op art. También, hay un resurgir de grupos artísticos entre finales de los años cincuenta y primeros de los sesenta: El Paso, Equipo 57, Grupo Hondo, Parpalló, Estampa Popular, Equipo Crónica, Zaj, Gaur, etc. Este ambiente es descrito por Francisco Calvo Serraller de la siguiente manera: la realidad artística de las jóvenes generaciones españolas enfatiza exageradamente la falta de apego a las señas de identidad heredadas, la voluntad firme de expresar una situación española que ha roto con el pasado; de expresar, en definitiva, como ya lo escribí en otra ocasión, la 'España del más allá de España' (180).

3 Destacan específicamente los manuscritos del 6 de mayo de 1962 y del 3 de octubre de 1963. Véase: Vilar, Sergio. Historia del antifranquismo 1939-1975. Barcelona: Plaza \& Janés, 1984. Medio impreso. 
Sabemos que el aislamiento del gobierno franquista hasta su acercamiento a las democracias occidentales influyó negativamente en la cultura española. Junto al informalismo, se observa la presencia de dos corrientes críticas que calarán con fuerza en territorio español: la neofiguración y el realismo social, los cuales tendrán un protagonismo visible para el panorama artístico español.

\section{De la Neofiguración al Realismo Social}

A partir de las restrictivas normas culturales y artísticas que se imponen en la España franquista, una serie de creadores se lanzan desde diversos ámbitos en un proceso de deslegitimización pictórica en torno a toda una serie de estereotipos culturales e históricos españoles. Sus lenguajes son diversos y alejados entre sí, pero les une un afán crítico de rebeldía ante opciones artísticas de carácter académico. Estos dos movimientos artísticos permiten que una serie de creadores españoles se embarquen en desmenuzar, desmembrar y distorsionar estereotipos pictóricos del arte español.

En torno al Realismo Social, debemos anotar que este movimiento artístico ha mantenido una mala prensa hasta fechas recientes debido a los planteamientos doctrinales marcados por el dogmatismo del realismo socialista. Las pautas formales del lenguaje figurativo, así como su denominación bajo la etiqueta de realismo social (Marchán Fiz), realismo político (Sager), figuración narrativa o reportaje o crónica de la realidad han generado la desconfianza de numerosos teóricos sobre esta tendencia, que parecía alejarse de la propia evolución experimental producida con las vanguardias.

Los primeros brotes de este movimiento de corte neofigurativo se producen tras la Segunda Guerra Mundial, con los pintores del grupo Kitchen Sink (D. Bomberg, F. Auerbach, L. Kossof) y los grupos de Estampa Popular, entre otros. En un principio, se muestra bajo la carencia de contenidos políticos y sociales, pero durante la década de los años sesenta recurre a propuestas marcadas por connotaciones y mensajes de tinte social. Por este motivo, se le ha equiparado en numerosas ocasiones con el arte de testimonio, es decir, aquella tendencia figurativa que se centra en la elección de temas y aspectos claramente identificados con la emisión de contenidos y mensajes.

Curiosamente, aunque esta modalidad se muestra de manera crítica a nivel político y social, dando testimonio de contenidos directos, sus herramientas son convencionales, en el sentido de perpetuar aquellos lenguajes que la vanguardia siempre ha intentado dinamitar. Quizás, el uso de los lenguajes habituales de figuración se deba a la necesidad y emergencia de clarificar al máximo los canales de comunicación y visualidad con el espectador, principal agente de la ecuación artística emisor-receptor. Su objetivo fue hacer uso del lenguaje convencional para desestructurar los propios entramados del poder tradicional.

Se admiten las mismas herramientas aplicativas que utilizan los artistas pop norteamericanos. Por esa razón, el realismo social, para muchos teóricos, no es más que una 
simple manifestación pospop. Sin embargo, se remarca una intencionalidad antagónica en ambas tendencias, ya que el pop norteamericano en ningún momento planteó desestabilizar y alterar las estructuras económicas, políticas y sociales con las que convivió, presentándose el artista con una actitud objetiva y alejada de premisas subjetivistas (Osterwold 9).

A contrapartida de todo esto, los artistas insertos en el realismo social alteran notablemente el sentido y el significado de sus representaciones, claramente enfocadas en una crítica directa hacia un sistema carente de salidas políticas. A pesar de esta misma utilización visual e iconográfica, se supera con creces la superficialidad que mantenía el pop internacional, especialmente el norteamericano, rechazando la exaltación del mundo de la mercancía y del objeto.

El pop, bajo una actitud conformista, es simple testigo del desarrollo económico y de las costumbres de una sociedad anglosajona, caracterizada por el consumismo y la valoración del mundo objetual, como mercancía del deseo emocional más que como verdadera necesidad material; en definitiva, un subproducto accidental de un estilo de vida (Stangos 190). En este sentido, el realismo social no hace uso de esta propaganda, sino que emplea sus medios, herramientas y formas visuales para desestructurar la misma sociedad que ensalza el pop, interviniendo de manera crítica, satírica e irónica una realidad que no se ajusta a las verdaderas necesidades sociales y políticas del ser humano.

Muchos artistas españoles mostraron su rebeldía y malestar mediante este lenguaje, haciendo gala de un compromiso social y político necesario para los tiempos que corrían. El número de artistas españoles que se mueven en determinados momentos bajo esta línea de acción artística es muy amplio: Juan Genovés, Equipo Crónica, Equipo Realidad, Rafael Canogar, Eduardo Arroyo y Alberto Corazón, entre otros.

El realismo político hace uso de imágenes producidas en los mass media de países más avanzados económicamente; se emplean símbolos e iconos, conocidos por una inmensa mayoría de espectadores, que posteriormente son derivados hacia una temática socio-política concreta. En España, por ejemplo, el tratamiento viene regulado por la violencia que ejerce el estado franquista ante los movimientos contrarios a su continuidad. Dentro de este apartado, las propuestas de Equipo Realidad, Juan Genovés y Rafael Canogar son relevantes al hacer muestra de la represión policial y militar sobre la juventud española.

Otro asunto dentro de esta línea de trabajo sería la propia denuncia en torno a diferentes costumbres, hábitos, estereotipos y mitos culturales, claramente observado en los tratamientos de Eduardo Arroyo, Equipo Realidad y Equipo Crónica. También se hace alusión temática a la alineación colectiva, la representación del hombre solitario, la crítica al consumismo, la publicidad y la manipulación de los medios. En definitiva, un uso múltiple de temáticas que vienen avaladas por una orientación ideológica que marca las connotaciones de los mensajes.

Nunca se podrá decir que el realismo social se ha mostrado indiferente ante la problemática política de cada lugar, ya que relaciona toda manifestación cultural con premisas sociopolíticas. Entre estas, una de las exposiciones más relevantes fue Arte y política de 1970 realizada en Alemania, tomando a artistas como A. Petersen, H.P. Alvermann, 
W. Vostell, Paeffgen, H.J. Breuste, G. Winner, K.P. Brehmer, entre otros. En esta exposición, se pusieron en entredicho las estructuras políticas, económicas y sociales existentes en la sociedad alemana desde perspectivas marxistas. Igualmente, en los Estados Unidos se ha observado esta realidad con muestras como Guerrilla Art, Moratorium y Violencia en el reciente arte americano, realizadas entre 1967 y 1970, donde toman parte artistas como Peter Saul, Larry Rivers y Guerrilla Art Action Group.

Estas exposiciones vienen acompañadas de diferentes debates y revisiones de la relación arte-política, siempre tratado desde posiciones izquierdistas. En Estados Unidos, tras cada exposición, se abrían debates especialmente relacionados con la problemática de la población negra, la intervención militar norteamericana en el exterior, la represión policial existente en los grupos de izquierdas y problemáticas referentes a los homosexuales y otras minorías. Podríamos decir que los temas que toman parte en estas exposiciones y en otras caracterizadas por el realismo social, asumen importancia desde el punto de vista político. En este sentido, la conexión arte-política bajo esta etiqueta artística resulta un pilar visible y fundamental.

El realismo político tuvo una notable relación con el Prop art o arte de propaganda o agitación ${ }^{4}$, claramente relacionado con los carteles del Mayo del 68 y carteles pertenecientes a otros grupos minoritarios y de izquierdas de los Estados Unidos, en los cuales se observaba un evidente uso ideológico del arte. El objetivo era emitir toda una serie de símbolos ideológicos, polémicos y subversivos ante el sistema establecido. Igualmente, en Estados Unidos, se observa otra tendencia muy cercana al realismo social: el movimiento underground denominado shocker pop. Curiosamente, este realismo que podría ser un arma arrojadiza de los diferentes malestares de los países del Tercer Mundo se convierte en un medio de expresión del malestar de numerosos grupos sociales y políticos de los países occidentales.

El término neofiguración o nueva figuración se caracteriza igualmente por su ambigüedad. Para Simón Marchán Fiz, “la ambigüedad de sus signos icónicos es paralela a las indecisiones y dudas entre su tendencia autocéntrica -centrada en el propio sujeto- y la alocéntrica -interesada por el objeto representado-" (28). A partir de los años sesenta se pone en relación con la representación icónica en el sentido de la imagen. Se trata de un lenguaje que imita al objeto que representa, que posee, algún rasgo común con la figura o forma que muestra. En este sentido, todo lo icónico conlleva una coincidencia con la forma pintada. En cualquier caso, el criterio de semejanza es relativista, perceptual y varía con el umbral de percepción (Verón 169). Este movimiento se apoya en el relativismo del criterio de semejanza mediante diferentes códigos perceptivos y de reconocimiento, produciéndose una gradación de iconocidad. Por otra parte, la relación con los contenidos del mensaje se manifiesta dependiendo del trato que se haga de los motivos iconográficos.

Bajo este movimiento, tampoco se ha dado una transformación radical de los soportes tradicionales. La neofiguración se enclava entre el informalismo y las tendencias

4 Resultan de gran interés las siguientes publicaciones: Yanker, Gary. Prop art: over 1000 contemporary political posters. New York: Darie House, 1972; Richardson, Jack. Prop Art. New York: New York Review of books, 1968; Reeder, R. Agit-Prop Art - Posters, Puppets, Propaganda And isenstein 'Strike. Russian Literature Triquarterly, 22 (1989): 255-278. 
representativas posteriores. Siendo más exactos, diremos que se trata de una transición entre el informalismo de los años cincuenta y su representación posterior: una figuración cada vez más interesada por liberarse de las indeterminaciones significativas. De ahí que, aunque se presente como una postura figurativa, recupere muchos procedimientos y elementos informales. En definitiva, una tendencia ambigua a la que se acogieron diferentes artistas, con lenguajes y posturas muy diversas.

Son numerosas las figuras internacionales que se han dado cita en esta nomenclatura artística, por ejemplo Willem de Kooning, Franz Kline y Jasper Johns. Igualmente, como puente de unión entre el informalismo y la nueva figuración, encontramos al grupo Cobra, De Staël y Dubuffet. Una de las principales figuras de este movimiento artístico fue el español Antonio Saura, que ya había deslumbrado al panorama internacional con sus obras desde mediados de los cincuenta. Igualmente, se ha tomado como punto de referencia, dentro de esta tendencia, al artista nacido en Dublín Francis Bacon, siendo visto como el pionero y principal representante de la neofiguración.

Estos artistas marcan los puntos de representación figurativa especialmente en rostros, ojos, cabezas y narices. El resultado es un trabajo que plantea preguntas de identificación y reconocimiento a partir del motivo. Se centran en figuras aisladas, sin aparentes relaciones contextuales, desconectadas de connotaciones sociales, generando una oscilación entre objetividad y subjetividad. Todas estas obras aprovechan la composición caótica, caógena y desestructurada del informalismo, pero siempre manteniendo ciertas pautas figurativas de reconocimiento y asimilación. Todas las imágenes representadas engendran su propio contexto, produciendo de este modo espacios vitales, donde la propia figura confirma su existencia, distanciándose de una ordenación euclidiana del espacio.

Este movimiento resulta interesante por el uso que hace de los espacios de contigüidad, separación y desarrollo. Estos, junto a las figuras, muestran propuestas deformadas al espectador, alteraciones anatómicas y deformaciones corporales mediante tratamientos interfigurales o entre distintas secciones corporales de una misma figura. En España, muchos de los artistas que se plantearon el trabajo con la neofiguración, tendieron un puente entre sus trabajos y las problemáticas políticas.

\section{Equipo Crónica: sátira y burla en torno a los estereotipos de la pintura española}

Este colectivo surge en 1964 y se compone de varios artistas, quedando un año después articulado únicamente por los creadores Rafael Solbes (1940) y Manuel Valdés (1942) ${ }^{5}$. El objetivo de Equipo Crónica era "iniciar un trabajo de colaboración cuyos presupuestos preten-

5 Este grupo ha tenido una notable repercusión con su temática crítica en Francia, destacando las siguientes exposiciones: Salón de la Jeune Peinture, Paris, 1965, 1967; España, arte y cultura, Aubervilliers, 1966; Le Monde en Question, Museo de Arte Moderno, Paris, 1967; Art et Racisme, Paris, 1971; VIII Bienal, Paris, 1973; Mythologies Quotidiennes II, Museo de Arte Moderno, Paris, 1977; Images Détourées, Centre Georges Pompidou, Paris, 1978; entre otras muchas. Su obra ha sido igualmente tratada por diversos teóricos franceses, como Francis Parent, Perrot Raymond y P. Gaudibert. 
dían ofrecer nuevas alternativas al panorama artístico de aquellos años" (Equipo Crónica 5). Una de sus primeras acciones fue sustituir su firma personal por la del nombre del colectivo.

Este grupo se crea en un ambiente agitado política y socialmente, en una época caracterizada por grandes huelgas que se extienden al ámbito universitario. En definitiva, un panorama social que mostraba una clara resistencia contra el régimen. Los conflictos laborales, especialmente, se recrudecen en Valencia a partir de 1962, coincidiendo con las huelgas de Asturias, las cuales obedecían al malestar provocado por los diversos ajustes de la estabilización y los métodos de racionalización en la organización del trabajo (Gómez Roda 52). Igualmente, los miembros de este colectivo se ven inmersos en la consolidación del movimiento estudiantil valenciano, de carácter clandestino, que planteaba una lucha por acabar con el sindicato único y obtener apoyos electorales ${ }^{6}$.

Solbes y Valdés encontraron en el movimiento de Estampa Popular un medio para expresar su compromiso y apoyo a dicha oposición. En paralelo a su actividad con el grabado, se iría desarrollando un trabajo pictórico alimentado por acontecimientos históricos y su contigua reflexión sobre el arte. Sus principales materiales de trabajo serían el linóleo y la serigrafía, siendo empleada esta última a partir de 1966. Dentro de este marco artístico, se empezarían a utilizar imágenes conocidas de la pintura clásica española confrontadas con otros ambientes y personajes contemporáneos. Los grandes protagonistas fueron las Meninas, Felipe IV, Carlos IV, el Conde-Duque de Olivares, la reina Mariana, Cayetana, imágenes-emblema que fueron sometidas a una continua desacralización y blasfemia visual. Para Michéle Dalmace-Rognon, estos artistas fueron:

creadores de alegorías, de una obra que pone en juego el pensamiento y la experiencia visual, no fueron generadores si no manipuladores de mitos y de símbolos.

[...] Al tratar los símbolos y los mitos, el Equipo hizo una llamada a la memoria colectiva, tal y como lo indican las referencias a las obras clásicas, la guerra civil, la educación en general (8).

Las principales características del Equipo Crónica giran en torno a un pluralismo estilístico, lo que explica sus relaciones con diversas tendencias y técnicas, generando una notable hibridez y eclecticismo en el lenguaje empleado. De hecho, hicieron gala de los distintos márgenes de representación, especialmente de los procedentes de los mass media, para su cometido crítico. No se plantea el uso unívoco de procedimientos estilístico-formales, sino que se aboga con claridad por su combinación y conjunción. Esto demuestra que nos encontramos ante artistas claramente activos y militantes en pro de una búsqueda de nuevas salidas para la figuración, pero bajo contenidos de rechazo, crítica y subversión política.

6 La Ley de Ordenación Universitaria, promulgada por Franco en 1943, establecía el control conjunto de la universidad por la Iglesia Católica y el Movimiento Falangista, apareciendo el Sindicato Español Universitario (SEU), que debía adoctrinar a los estudiantes en el espíritu del régimen. La paulatina pérdida de protagonismo de la Falange en la vida cultural español sería sustituida por tecnócratas vinculados al gobierno y al nacionalcatolicismo. Entre los distintos sindicatos clandestinos aparecen la Federación Universitaria Democrática Española (FUDE) de Madrid en 1961. La FUDE tendrá un fuerte protagonismo en los ámbitos universitarios valencianos. Véase Maravall, José María. Dictadura y disentimiento político. Obreros y estudiantes bajo el franquismo. Madrid: Ediciones Alfaguara, 1978. Medio impreso. 

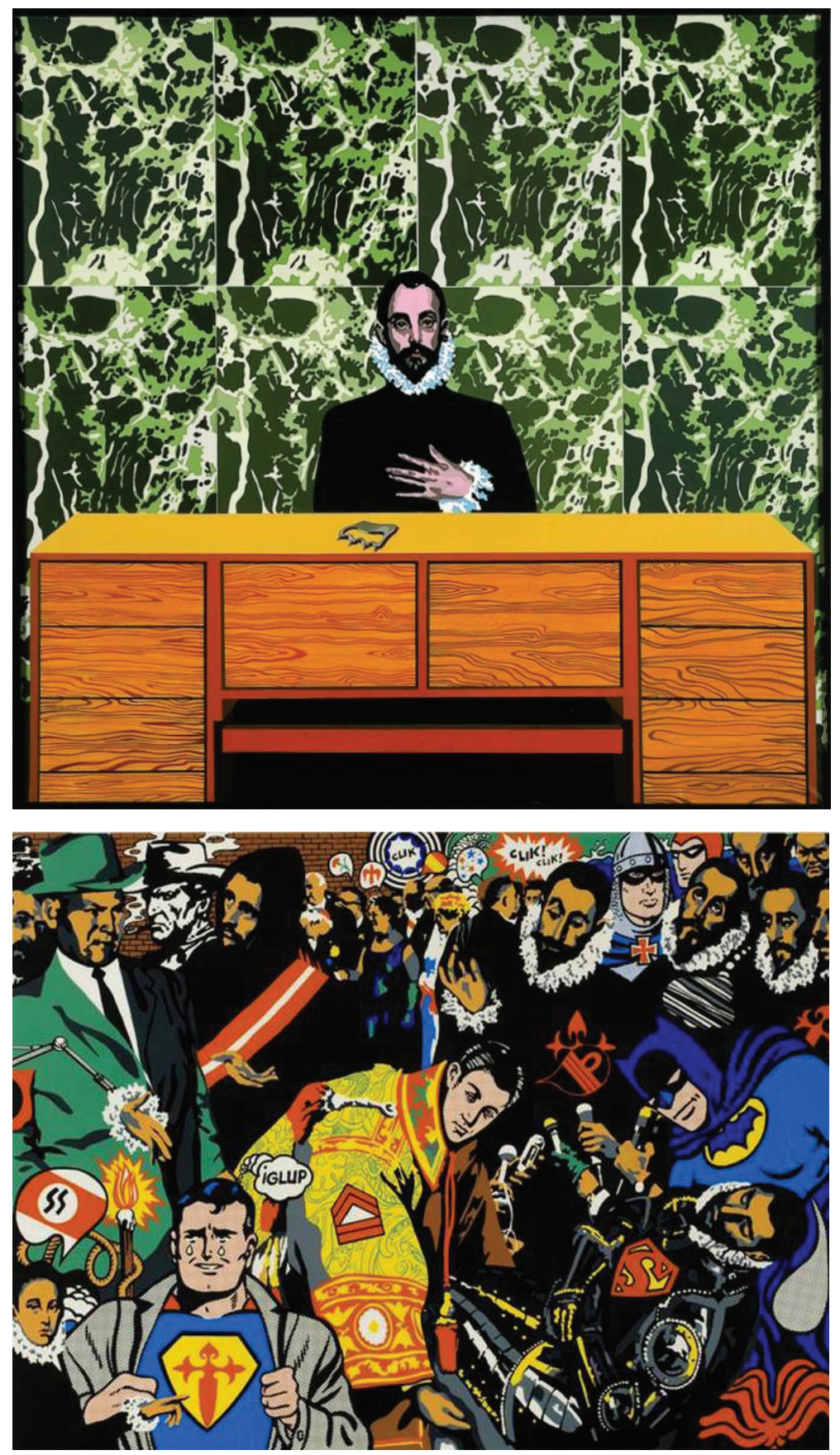

Figura 1 (arriba). Equipo Crónica. La antesala, 1968. Fundación March. Figura 2. Equipo Crónica. El entierro del Conde Orgaz, 1969. Museo de Arte Contemporáneo de Alicante. 


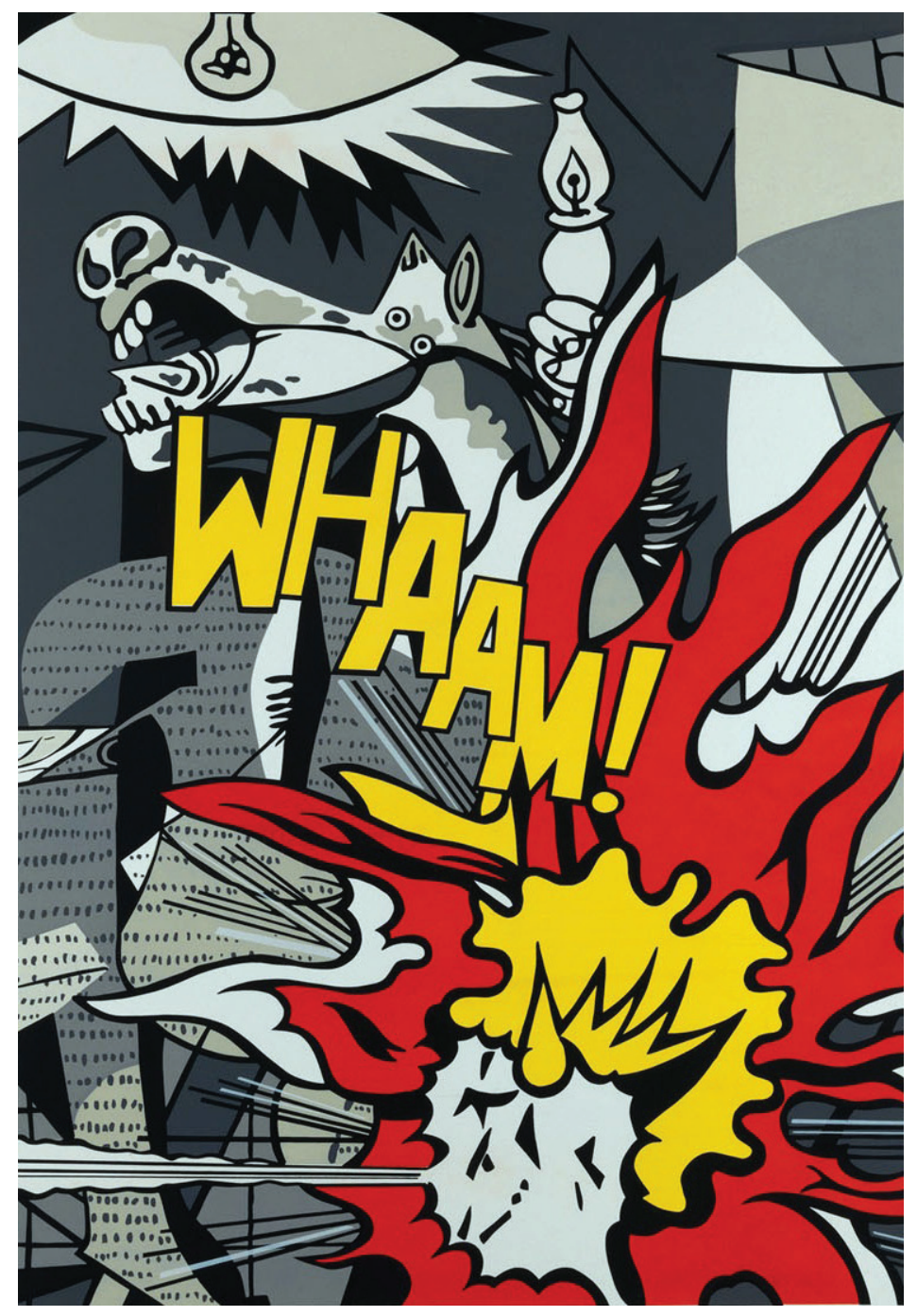

Figura 3. Equipo Crónica. Guernica, 1971. 


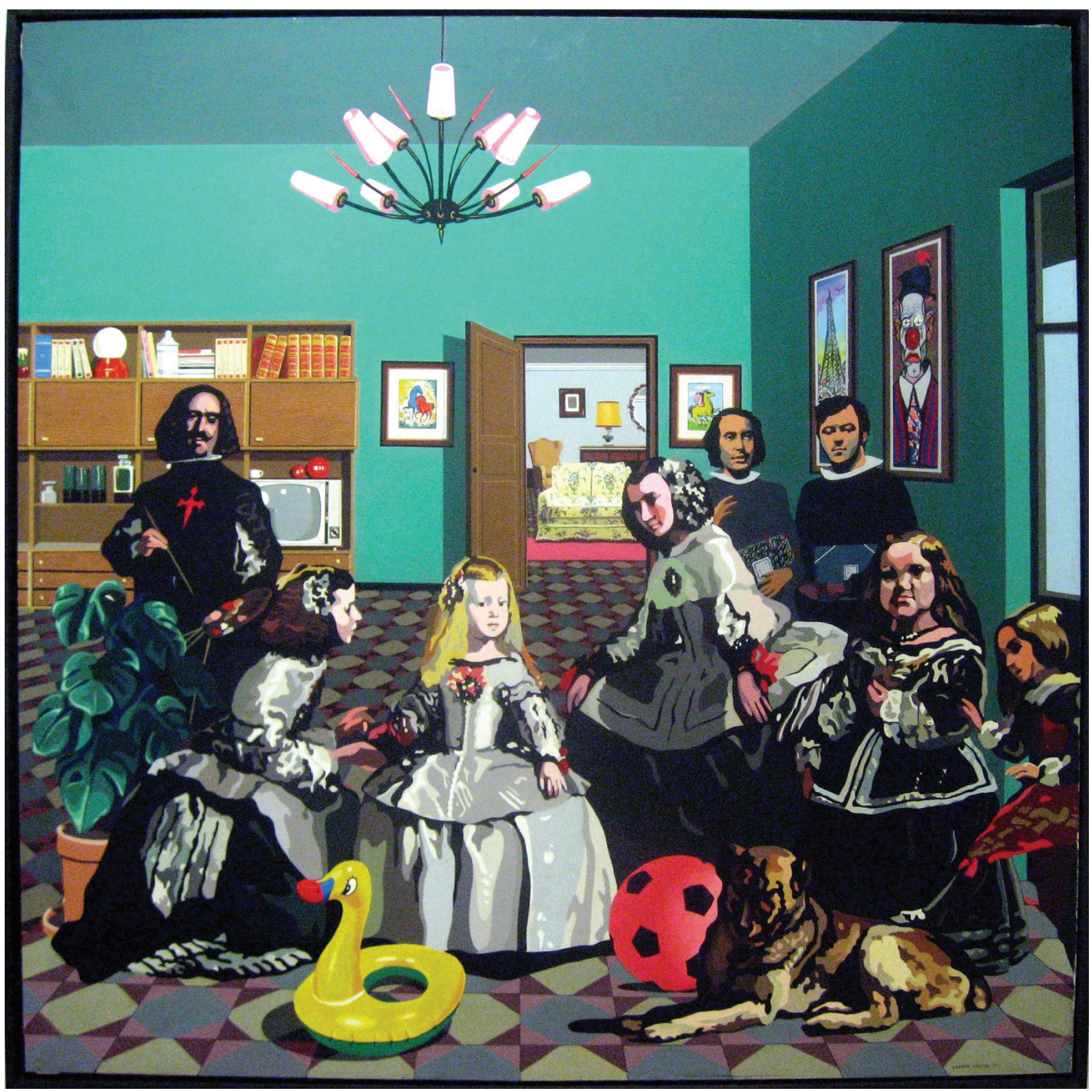

Figura 4. Equipo Crónica. Las Meninas, 1970. Fundación Juan March, Madrid. 
Entre las diferentes herramientas empleadas, encontramos las siguientes: 1.- Las técnicas fotográficas que, por una parte, se mueven cercanas al verismo realista de Fanti, Erro, Monory y, por otra, se presentan con alteraciones y descontextualizaciones en lo que respecta a las imágenes; 2.- Los planteamientos procedentes del cine respecto a cuestiones temporales y de movimiento, mediante numerosas divisiones del cuadro en diferentes partes que se relacionan con las distintas fases del mismo suceso cinematográfico narrado; 3.- Los referentes extraídos del comic. Debido a su validez comunicativa, en todos los estratos sociales, se aboga por imágenes y medios visuales que resulten familiares para los espectadores; 4.- La incorporación de distintas imágenes y formas visuales al original con el propósito de generar simbolismos y asociaciones narrativas dentro de los contenidos de la obra. En numerosos trabajos, se contraponen imágenes y escenas procedentes de cuadros de maestros españoles de la pintura del Siglo de Oro con contextualizaciones y ambientaciones contemporáneas, con el propósito de ironizar y satirizar sobre las imposiciones políticas y académicas del régimen. En definitiva, se trataría de un menosprecio por la teoría artística española del Siglo de Oro (Serraller 20). Para Valeriano Bozal:

la recuperación de los motivos más conocidos de la pintura española del Siglo de Oro -y algunos de la obra goyesca- implica la extensión a estas imágenes de la consideración de imágenes de los media: como estas, constituyen el patrimonio visual consagrado y canonizado, ahora ideológicamente, que está al alcance de todos los españoles. Los cuadros del Greco, de Velázquez y Goya han sido reproducidos incontables veces y forman parte de la historia visual, pero también política, social y cultural de nuestro país. En su formar parte, dan un sentido a la historia, sentido del que se reclaman los gobernantes, los defensores del Imperio y la España de los Austrias, de la tradición. Estas imágenes sirven, aunque no se lo hubieran propuesto, para configurar las señas de identidad de un presente histórico. Al recontextualizarlas se hace evidente que semejante reclamo es consecuencia de un proceso político, no una cualidad natural de las imágenes (46).

Este tratamiento responde a planteamientos de descontextualización y extrañamiento conocidos como ostranenie ${ }^{7}$. Bajo esta técnica, se produce la separación de una imagen de su contexto habitual y original siendo no solo una alteración del lenguaje, sino también de sus contenidos simbólicos. Este tipo de procedimientos tiene una clara relación con el género de las parodias críticas. De hecho, el fenómeno llegó a ser habitual en la obra de muchos artistas europeos, mostrándose como un medio crítico y subversivo ante una realidad cultural que no satisfacía en nada a los artistas. En este sentido, este colectivo realiza parodias culturales que arremeten contra mitos como El Greco, Velázquez, Ribera, Zurbarán y Goya, entre otros. Propuestas donde se reproducen las principales figuras elaboradas por los anteriores maestros de la pintura mezcladas con otros personajes

7 Para más información sobre este concepto, remitirse a Marchán Fiz, Simón. Del arte objetual al arte de concepto (1960-1974). Epílogo sobre la sensibilidad posmoderna. Torrejón de Ardoz: Akal, 1990: 72-73. 
extraídos de la propia cultura del momento, claramente relacionada con la imaginería de los mass media, invalidando su autenticidad original. El historiador del arte Tomás Llorens analiza este tema de la siguiente manera:

La pintura española del Siglo de Oro, mito colectivo de la España contemporánea, herencia cultural, presente, como en filigrana, en el imaginario colectivo, constituye para Rafael Solbes y Manolo Valdés el campo más evidente de elección de materiales pictóricos. [...] La crítica de la época tendía a ver en la apropiación de imágenes procedentes de la historia del arte una actitud puramente negativa, de rechazo del mito (20).

Por ejemplo, en Las estructuras cambian, las esencias permanecen (1968) observamos dentro de una oficina tecnificada a personajes pintados por Velázquez, El Greco, Zurbarán y Goya, que guardan fielmente la actitud literal que mantienen en sus cuadros originales. De hecho, las imágenes son extraídas de los siguientes cuadros: El caballero de la mano en el pecho (El Greco) de 1577-84; Retrato del Conde-Duque Olivares (Velázquez) de 1634; un cartujo del cuadro La Virgen de Los Cartujos (Zurbarán) de 1658; y el retrato de la Duquesa de Alba (Goya) de 1795. Estas figuras quedan totalmente trastocadas y alteradas al ser descontextualizadas tanto en el espacio como en el tiempo.

En otra obra, Juegos peligrosos, se observa cómo la figura de Felipe IV, pintada por Velázquez en 1627, disecciona uno de los miembros pertenecientes al Guernica de Picasso; una mutilación simbólica realizada por parte de la pintura más histórica hacia uno de los íconos del arte moderno y hacia su autor, relacionado con el Partido Comunista, siendo su figura, de hecho, algo aborrecible para el régimen franquista.

Las primeras descontextualizaciones de personajes pintados por los maestros clásicos de la pintura española empiezan ya en el año 1964 con trabajos como El desfile, para posteriormente lanzarse a diferentes series como La recuperación de 1967-1969, Guernica 69 y Autopsia de un oficio, de 1969-70. Estos aspectos irán remitiendo paulatinamente durante la década de los setenta; no obstante, debemos anotar que en los años 1972-73, se realiza la serie Retratos, bodegones y paisajes, donde se vuelve a jugar con ciertas imágenes-mito de carácter clásico. Tras esta serie, en El Cartel, Oficio y Oficiantes, La subversión de los signos, La Trama, La partida de billar y otras más, la anterior preocupación representativa queda definitivamente aparcada.

\section{Antonio Saura: la alteración formal de los estereotipos de la pintura española}

Bajo un lenguaje cercano a la neofiguración que se da a partir de finales de los años cincuenta, Antonio Saura (1930-1998), uno de los artistas más renombrados dentro del panorama europeo, se lanza a un proyecto experimental que distorsiona formalmente las principales figuras pictóricas, culturales e históricas del país. 


$$
1
$$



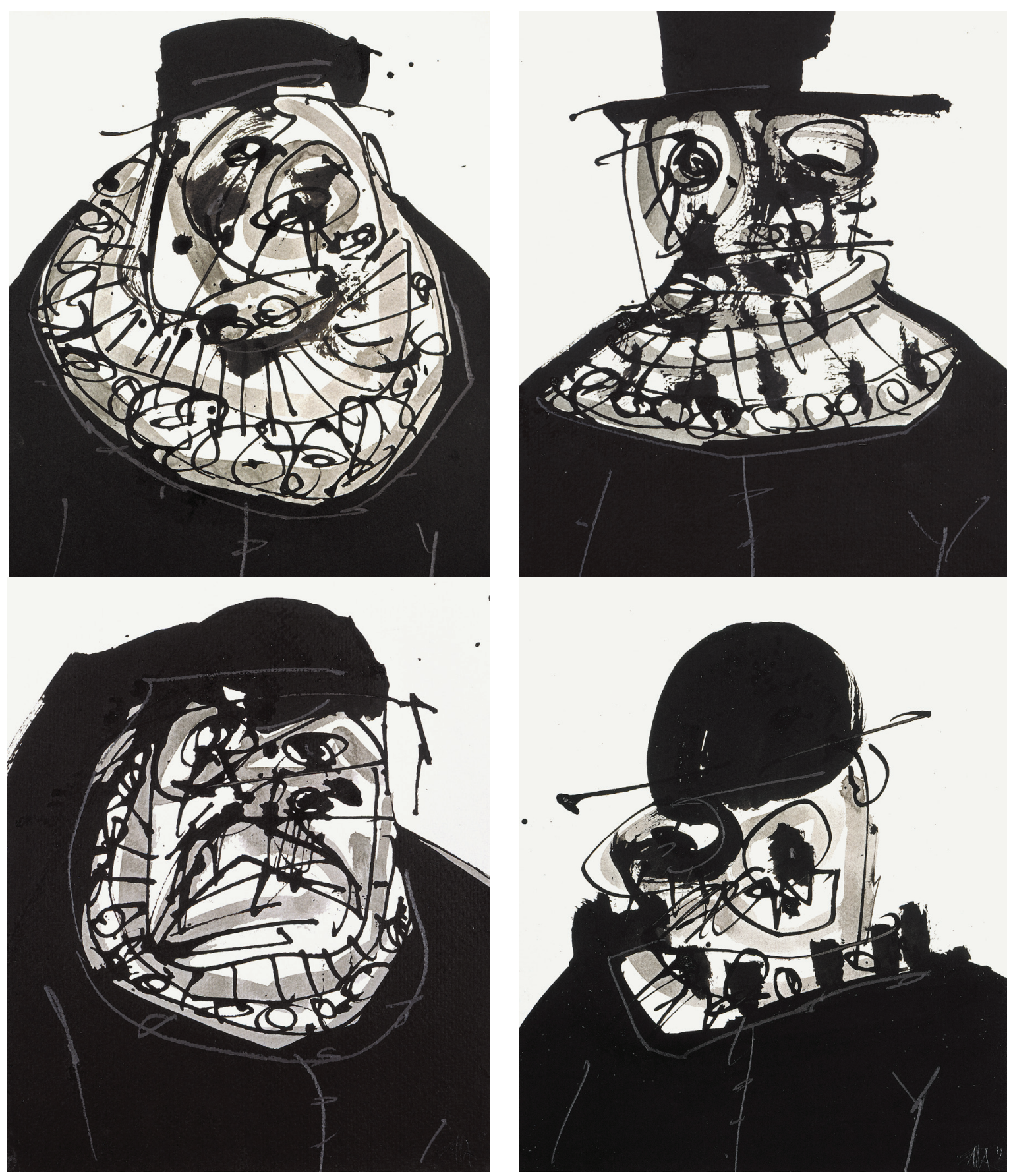

Figura 5 (izquierda), 6, 7, 8 y 9. Antonio Saura. Retrato imaginario de Felipe // (serie), 1987. Galería Boisserée, Köln und VG Bild-Kunst, Bonn. Fuente: Art Cologne. Sitio web. 
Influenciado por el surrealismo, así como por el informalismo, que adquiere gran prestigio y peso social en los círculos intelectuales más contestatarios del país, y marcado por un espíritu rupturista, no alejado de cierta polémica en la época, arremete en sus Retratos imaginarios con violencia creativa contra estos estereotipos que se identifican con los baluartes representativos del régimen. Nos estamos refiriendo nuevamente a imágenes y personajes pintados por Velázquez y Goya. Su propuesta no solo se adentra desde el punto de vista más formal y pictórico: subyace una intención de polemizar con la habitual contingencia de la enseñanza más académica.

En su galería de personajes históricos encontramos las representaciones de Felipe II y Carlos IV, entre otros. Esta línea de trabajo ha sido definida por el artista como: "galerías de ancestros, necesariamente limitada, donde la personal repulsa es practicada con delectación y ternura" (Saura 55). Todas estas obras quedan dominadas por un temperamental color negro, siendo en muchas ocasiones muy limitado el abanico de colores. De hecho, su obra se caracterizó por la influencia de lo trágico, lo barroco, mediante su marcado tenebrismo.

La tendencia se marca hacia lo monstruoso como resultado de un conflicto del artista con la propia representación. Por muy inaprensibles que pueden ser los cuadros de Saura, siempre acaban formando imágenes. El artista no suele hablar de retratos, sino de un encuentro con una imagen ya deseada a través de algunos signos que la hacen posible, refiriéndose con más exactitud al espectro de la misma. De ahí, todas las representaciones imaginarias de Felipe II, articuladas a partir del estudio de los famosos retratos realizados por Tiziano en 1550-51 y 1554, Antonio Moro en 1572, Sánchez Coello en 1566 y especialmente Sofonisba Anguissola en 1573. No obstante, uno de los principales referentes pictóricos que tomará en cuenta Antonio Saura serán las pinturas negras de Goya. Como bien afirma la escritora Dore Ashton: "la morfología del espacio propio de Saura rige estas pinturas y siento profundamente que ha conseguido revelar del abismo emocional de Goya, de su esencia más enigmática” (6). Ha sentido fascinación desde niño por el Perro de Goya, situado en el Museo del Prado, relacionándola con el recuerdo del patito feo de los cuentos infantiles. Como indica Rainer Michael Mason: "el perro bosquejado por Goya en la pared de la Quinta del Sordo, es para Antonio Saura, casi sin duda alguna, como la escena primitiva de toda pintura -y del universo mismo. Retrato emblemático de Goya, que lo habrá probablemente pintado con una ironía mezclada de temor" (21).

Toda su obra se basa en una desestructuración anatómica y formal generada por una visión distorsionada y alejada de las pautas más clasicistas del arte. Todos los aspectos anatómicos quedan reducidos a su presencia más elemental, siendo sometidos a todo tipo de alteraciones y dislocaciones. Tal como lo comenta el propio artista, con todas estas figuras históricas se trata "de activar una imagen obsesiva y ancestral sin que ello suponga una regresión a estructuraciones clásicas, mediante el empleo de un soporte emocional y físico no dependiente de un proceso intelectual de síntesis, transposición o abstracción" (Saura 15). Siempre se buscan los aspectos más extremos, siendo casi una aniquilación de toda forma tradicional en su estética, de ahí que urja de la violencia en el trazo, la composición y el desarrollo pictórico. 
En España, se han realizado numerosas crucifixiones, retratos y representaciones de damas cortesanas, especialmente las de Goya, que vuelven a ser retomadas bajo la brocha de este artista, pero bajo una categorización totalmente distorsionada. Como indica Rainer Michael Mason: "la visión de Saura saca sus energías de la cultura y de las coacciones de España” (21). Este artista pinta todo lo que acontece al ser humano, con sus convicciones y traiciones, sus afectos y enemistades, con sus cabezas, que son morada de pesadillas y se vuelven monstruosas. De ahí sus representaciones de Felipe II como un monstruo, totalmente deformado y alejado de la estética clasicista de la pintura tradicional española.

En el caso de las crucifixiones, estas empiezan a elaborarse a partir de 1957, pero no obedecen a motivos religiosos. Desde niño, le ha obsesionado el Cristo crucificado (1632) de Velázquez, situado en el Museo del Prado de Madrid, con su rostro oculto entre las negras cabelleras. El artista es conocedor de las distintas crucifixiones elaboradas por el Greco (Cristo en la cruz de 1590); Alonso Cano (La Crucifixión de 1640 y esculturas sobre la misma temática); Zurbarán (San Lucas como pintor ante Cristo en la cruz de 1630); Murillo (San Francisco abrazado a Cristo en la cruz de 1668) y Francisco Pacheco (Cristo crucificado de 1614). De estos artistas extrae el negro, especialmente de Velázquez, agudizando la sensación de un cuerpo torturado. Todos estos aspectos se unen a su interés por dar una sensación de protesta, rozar lo blasfematorio, tanto en su contenido como en su visión estética y formal. Igualmente, el artista se ve inmerso y reflejado en el crucificado como un ser solitario ante un universo amenazante, quedando reflejados, de este modo, la angustia y la tragedia del hombre.

\section{Referencias}

Abellán, Manuel L. Censura y creación literaria en España (1939-1976). Barcelona: Ediciones Península, 1980. Medio impreso.

Allport, G.W. The nature of prejudice. Reading: Addison-Wesley, 1954. Medio impreso.

Ashton, Dore. Antonio Saura. Obra sobre papel 1956-1995. Madrid: Galería Marlborough, 1999. Medio impreso.

Bozal, Valeriano y Tomás Llorens. España. Vanguardia Artística y Realidad Social: 1936-1976. Barcelona: Gustavo Gili, 1976. Medio impreso.

---. Cuatro notas para el análisis de las imágenes del Equipo Crónica. Equipo Crónica. Valencia: IVAM, 1989. Medio impreso.

Dalmace-Rognon, Michéle. Equipo Crónica. Catalogación de Obra Gráfica y Múltiples. 1965-1982. Bilbao: Museo de Bellas Artes de Bilbao, 1988. Medio impreso.

Equipo Crónica. Equipo Crónica. Madrid: Taller Ediciones JB, 1976. Medio impreso.

Fishman, J. A. "An examination of the process and function of social stereotyping". Journal of Social Psychology 43 (1956): 27-64. Medio impreso. 
Gómez Roda, J. Alberto. Comisiones Obreras y represión franquista. Valencia 1958-1972. Valencia: Universitat de Valencia, 2004. Medio impreso.

Katz, D. y K. Braly. "Racial prejudice and racial stereotypes". Journal of Abnormal and Social Psychology 30 (1935): 175-193. Medio impreso.

Llorens, Tomás. “Equipo Crónica: La amistad y la palabra”. Equipo Crónica. Catálogo razonado a cargo de Michéle Dalmace. Valencia: IVAM, 2001. Medio impreso.

Malerbe, Pierre C. La oposición al franquismo 1939-1975. Madrid: Ediciones Naranco, 1977. Medio impreso.

Marchán Fiz, Simón. Del arte objetual al arte de concepto (1960-1974). Epílogo sobre la sensibilidad posmoderna. Torrejón de Ardoz: Akal, 1990. Medio impreso.

Mason, Rainer Michael. “La escena primitiva”. Antonio Saura. La obra gráfica 1958-1984. Madrid: Dirección General de Bellas Artes y Archivos, 1985. Medio impreso.

Muniesa, Bernat. Dictadura y monarquía en España. De 1939 hasta la actualidad. Barcelona: Editorial Ariel, 1996. Medio impreso.

Osterwold, Tilman. Pop Art. Köln: Taschen, 1992. Medio impreso.

Sager, Peter. Neue Formen des Realismus. Cologne: Verlag M. DuMont Schauberg, 1974. Medio impreso.

Saura, Antonio. “Historia de España”. Antonio Saura. La obra gráfica 1958-1984. Madrid: Dirección General de Bellas Artes y Archivos, 1985. Medio impreso.

---. “Iniciales”. Antonio Saura. Pinturas 1956-1985. Madrid: Ministerio de Cultura. Centro de Arte Reina Sofía, 1989. Medio impreso.

Serraller, Francisco. Del futuro al pasado. Vanguardia y tradición en el arte español contemporáneo. Madrid: Alianza Forma, 1988. Medio impreso.

Soto Carmona, Álvaro. “Desarrollo político e institucionalización, 1957-1969”. Historia de la España actual: 1939-1996. Autoritarismo y democracia. Barcelona: Ediciones Marcial Pons, 1998. Medio impreso.

Stangos, Nikos. Conceptos de arte moderno. Madrid: Alianza Editorial, 1981. Medio impreso. Ureña, Gabriel. Las vanguardias artísticas en la postguerra española. 1940-1959. Madrid: Ediciones Istmo, 1982. Medio impreso.

Verón, E. Conducta, estructura y comunicación. Buenos Aires: Editorial Jorge Álvarez, 1968. Medio impreso.

Recibido: 26 septiembre 2012

Aceptado: 22 marzo 2013 